\title{
Effect of isoproteinous feed on growth and survival of tilapia (Oreochromis niloticus) fry
}

\author{
I. Siddika, M. Das and K. R. Sumi \\ Department of Aquaculture, Bangladesh Agricultural University, Mymensingh-2202, Bangladesh \\ Email: sumi.02bau@gmail.com
}

\begin{abstract}
A four week experiment was conducted to evaluate the effect of isoproteinous (35\%) feed prepared named diet 1,2 , 3 and 4 respectively by substituting $0 \%, 50 \%, 75 \%$ and $100 \%$ fish meal with meat and bone meal in view of preparing a cost effective tilapia (Oreochromis niloticus) fry feed. The four experimental diets (diet 1 to 4 ) each were randomly assigned to twelve hapas with three replications. Tilapia fry $(0.011 \mathrm{~g})$ were randomly stocked in $100 \mathrm{fry}^{\mathrm{f}} / \mathrm{ft}{ }^{2}$ hapa and fed five times a day up to their apparent satiation. The results of the study showed that the weight gain, specific growth rate (SGR), the apparent net protein utilization value and survival (\%) of the fish were significantly $(P<0.05)$ higher and better feed utilization with lower FCR value was observed in fish fed on the diet 4 where meat and bone meal was used as sole source of protein base. There was no significant difference between the carcass moisture and lipid of fish fed with different experimental diets. The results of the study indicated that diet 1 containing fish meal (45.15\% Fish meal, 27.43\% Rice bran and $27.43 \%$ Wheat flour) can be replaced by meat and bone meal containing diet 4 (54.06\% Meat and bone meal, 22.97\% Rice bran and 22.97\% Wheat flour) with no adverse effects on growth and survival of $O$. niloticus. Before recommendation several trials will be necessary in different farms to be sure of the reproducibility of the result obtained in the present experiment. Cost- benefit analysis reveals that the meat and bone meal containing diet certainly provides cheaper feed.
\end{abstract}

Keywords: Tilapia fry, Isoproteinous feed, Growth and survival

\section{Introduction}

Culture of tilapia in our country became popular because of its excellent growth rate, ability to take variety of artificial feeds, high resistance to poor water quality and also due to its disease resistance. It grows to market size within short period of time and its survivality is also very high. In tilapia culture quality fry supply is one of the bottlenecks for its extension. To produce quality fry appropriate and economically viable fry feed is important. Most of the hatchery owners do not know the appropriate requirement of protein percentage in feed. It has not been standardized as a result the quality of seed is not always good. Earlier experiments suggest that around 35\% protein containing diet is suitable for tilapia culture (Sumi, 2011). But the high cost of feed $(40 \mathrm{Tk} / \mathrm{kg})$ is limiting the fry rearing.

Fish meal is used as major protein source in most of the diets for finfish and crustacean species but it is most expensive. The price of meat and bone meal is comparatively lower than that of fish meal (Habib et al., 2001) and these ingredients are also commercially available in the market. For that, meat and bone meal (MBM) can be considered as an alternative of fish meal component for aquaculture feeds. If appropriate protein percentage was given better growth performance and quality seeds with less mortality could be expected. On the other hand for the use of costly ingredients like fish meal fry production is becoming economically less benefited. If feed is prepared from meat and bone meal with high protein content then it may reduce the feed cost without hampering the growth of fry and as such fry production can be sustainable.

Considering all those, a research work was undertaken to prepare isoproteinous low-cost fish feed for Tilapia fry (O. niloticus) production by replacing different quantity of fish meal and to recommend the maximum level of replacement of fish meal by meat and bone meal to prepare a cost effective diet. 


\section{Materials and Methods}

The experiment was conducted in Agro 3, fish hatchery and culture farm situated at Boilor under Trishal upazila in Mymensingh for a period of 28 days to determine the effects of isoproteinous feeds on growth and survival of tilapia (O. niloticus) fry in synthetic hapa from $20^{\text {th }}$ September to $17^{\text {th }}$ October 2011.

Four experimental diets viz diet 1, diet 2, diet 3 and diet 4 were prepared by replacing 0, 50, 75 and 100\% fish meal with MBM (Table 1).

Table 1. The composition of feed ingredients and its formulation used in 4 different experimental diets

\begin{tabular}{|c|l|c|}
\hline Diets & \multicolumn{1}{|c|}{ Description of diet } & $\begin{array}{c}\text { Protein content } \% \\
\text { (Formulated value) }\end{array}$ \\
\hline Diet 1 & Fish meal: Rice bran: Wheat flour $=45.15 \%+27.43 \%+27.43 \%$ & 35 \\
\hline Diet 2 & $\begin{array}{l}\text { Fish meal: Meat and bone meal: Rice bran: Wheat flour }=22.5 \%+ \\
27.11 \%+25.19 \%+25.19 \%\end{array}$ & 35 \\
\hline Diet 3 & $\begin{array}{l}\text { Fish meal: Meat and bone meal: Rice bran: Wheat flour }=11.25 \% \\
+40.59 \%+24.08 \%+24.08 \%\end{array}$ & 35 \\
\hline Diet 4 & $\begin{array}{l}\text { Meat and bone meal: Rice bran: Wheat flour }=54.06 \%+22.97 \% \\
+22.97 \%\end{array}$ & 35 \\
\hline
\end{tabular}

Proximate composition of the dietary ingredients and test diets were determined following the standard methods given by Association of Official Analytical Chemists (AOAC, 2000).

Two days old fry of initial average length of $0.8 \mathrm{~cm}$ and weight of $0.011 \mathrm{~g}$ were released in hapa at the same stocking density of $100 \mathrm{fry} / 9 \mathrm{ft}^{2}$. The water depth of experimental hapa was maintained at $2.5 \mathrm{ft}$. The fry of all the treatments (diet 1, 2, 3 and 4) were fed five times a day up to apparent satiation level. At the beginning of the experiment randomly selected fish fry sample from the stock was sacrificed and used for proximate composition analysis. This was considered as initial carcass composition of fish fry. At the end of experiment a pooled fish sample from all three replicate of four diets were sacrificed and used for final carcass composition analysis.

Sampling was carried out at an interval of 7 days where fry were caught by a scoop net and kept in a bowl with water. Total length and weight were recorded by using a scale and digital balance (AND GULF, Dubai, U.A.E., Model: GL-300). After recording the length and weight the fry were released in the respective hapa. The following parameters were used to evaluate the growth performance of fry.

Length gain $(\mathrm{cm})=$ Mean final length - Mean initial length

Weight gain $(\mathrm{g})=$ Mean final weight - Mean initial weight

Specific growth rate $(\mathrm{SGR} \%$ per day $)=\frac{\left(\log _{\mathrm{e}} \mathrm{W}_{2}-\mathrm{Log}_{\mathrm{e}} \mathrm{W}_{1}\right)}{\left(\mathrm{T}_{2}-\mathrm{T}_{1}\right)} \times 100$ (Brown, 1957)

Where, $W_{2}=$ Final live body weight $(\mathrm{g})$ at time $T_{2}$

$\mathrm{W}_{1}=$ Initial live body weight $(\mathrm{g})$ at time $\mathrm{T}_{1}$

Food conversion ratio $(F C R)=\frac{\text { Feed fed }(\text { dry weight })}{\text { Live weight gain }}$

Apparent net protein utilization (ANPU) (\%) $=\frac{N_{a}-N_{b}}{N_{i}} \times 100$

Where, $N_{a}=$ the body nitrogen at the start of experiment

$\mathrm{N}_{\mathrm{b}}=$ the body nitrogen at the end of experiment

$\mathrm{N}_{\mathrm{i}}=$ the amount of nitrogen ingested

Survival rate $(\%)=\frac{\text { Total number of harvest }}{\text { Total number of stock }} \times 100$ 
An economic analysis was performed to estimate the cost $(T \mathrm{k} / \mathrm{kg})$ of experimental diet. One way analysis of variance (ANOVA) was performed to test the significance of variation among the treatment means. Statistical tests were performed by computer based statistical software SPSS (Statistical Package for Social Science).

\section{Results and Discussion}

The formulated and actual protein content of different diets used in the experiment is given in Table 2. Growth increments of tilapia fry at 7 days interval in four treatments during the experimental period are shown in Fig. 1.

Table 2. Proximate composition of different experimental diets

\begin{tabular}{|l|c|c|c|c|c|c|}
\hline Name of item & \% moisture & \% lipid & \% Crude protein & \% Ash & \% Crude fibre & \%Carbohydrate \\
\hline Feed-1(control) & 21.85 & 12.09 & $35.08(35)$ & 7.18 & 4.20 & 19.61 \\
\hline Feed-2 & 21.64 & 14.81 & $32.63(35)$ & 8.40 & 4.35 & 18.17 \\
\hline Feed-3 & 20.93 & 13.37 & $30.27(35)$ & 9.34 & 4.70 & 21.39 \\
\hline Feed-4 & 18.84 & 14.24 & $33.83(35)$ & 10.75 & 4.60 & 17.75 \\
\hline
\end{tabular}

The figures in the parenthesis indicate formulated protein content

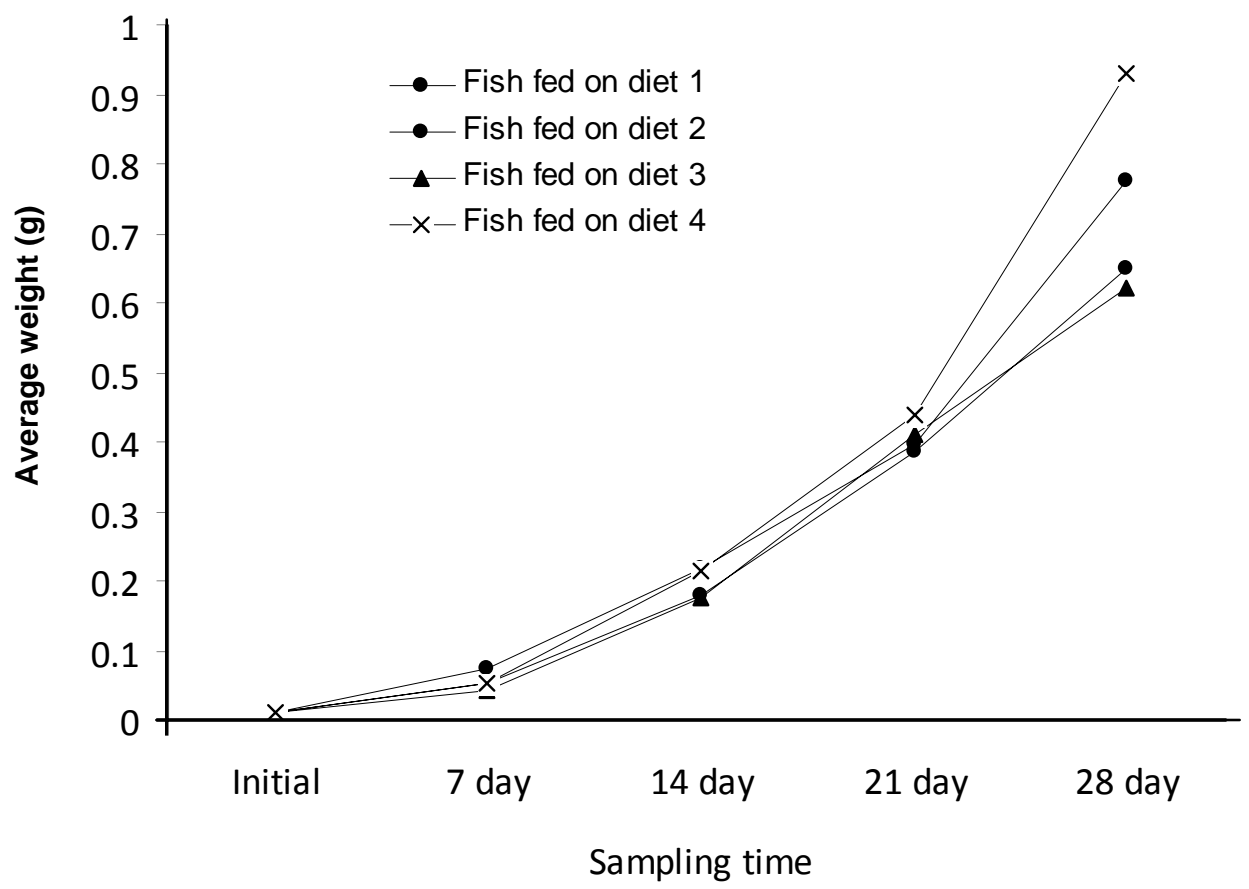

Fig. 1. Weekly growth responses (g) of tilapia (Oreochromis niloticus) fry fed with various diets during the experimental period

Growth performance of tilapia fry fed on different diets in terms of weight gain, specific growth rate (SGR $\% /$ day), food conversion ratio (FCR), survival rate (\%) and apparent net protein utilization (\%) were calculated (Table 3 ). The average weight gain by the fish during 28 days of culture showed significantly $(P<0.05)$ higher weight gain $(0.87 \mathrm{~g})$ in fish fed on the diet 4 and lower weight gain $(0.61 \mathrm{~g})$ in fish fed on the diet 3 . Better weight gains have been shown by the tilapia fry where $100 \%$ fish meal was substituted and lowest weight gain was exhibited by the fry fed feed where $75 \%$ fish meal was replaced by the meat and bone meal. The highest weight gain in diet 4 might be due to the fact that the fish received required protein and high amount of lipid in the diet. The lowest weight gain in diet 3 might be due to the fact that the fish had received low protein in the feed. 
Diet 4 showing higher specific growth rate (SGR) than that of fish meal containing diet 1 (control) has been shown in Table 3. The higher SGR values might be due to the higher amount of lipid (energy content) in the feed. Ogunji et al. (2007) worked on $4-5 \mathrm{~g}$ fingerlings and reported SGR value of 3.39 at the dietary protein content of $33.32 \%$. The mean food conversion ratio (FCR) of different experimental diets ranged between 1.01 and 1.52 (Table 3$)$. The significantly $(P<0.05)$ lowest FCR $(1.01)$ was found in diet 4 while the highest (1.52) was obtained in diet 3 . The survival rate varied from $77.45 \%$ to $97 \%$ in different treatments. Maximum survival rate was found in fish fed on the diet 4 . Survival rate as much as $98 \%$ was found in O. niloticus reared in pond by Michael and Jian (2002). Sumi (2011) found a survival rate of $94 \%$ by feeding $36 \%$ protein diet based on fish meal.

Table 3. Statistics of growth parameters and feed utilization of tilapia fry under different treatments during the experimental period (Mean \pm SD)

\begin{tabular}{|l|c|c|c|c|}
\hline Parameters & Diet 1 (control) & Diet 2 & Diet 3 & Diet 4 \\
\hline Mean initial Weight(g) & $0.011 \pm 0.00$ & $0.011 \pm 0.00$ & $0.011 \pm 0.00$ & $0.011 \pm 0.00$ \\
\hline Mean final Weight(g) & $0.77 \pm .07^{\mathrm{ab}}$ & $0.65 \pm .13^{\mathrm{b}}$ & $0.62 \pm .04^{\mathrm{b}}$ & $0.88 \pm .11^{\mathrm{a}}$ \\
\hline Weight gain (g) & $0.76 \pm 0.07^{\mathrm{ab}}$ & $0.64 \pm 0.12^{\mathrm{b}}$ & $0.61 \pm 0.15^{\mathrm{b}}$ & $0.87 \pm 0.11^{\mathrm{a}}$ \\
\hline SGR (\%/ day) & $16.32 \pm .36^{\mathrm{ab}}$ & $15.65 \pm .73^{\mathrm{ab}}$ & $15.45 \pm .88^{\mathrm{b}}$ & $16.85 \pm .45^{\mathrm{a}}$ \\
\hline FCR (\%) & $1.20 \pm .08^{\mathrm{ab}}$ & $1.44 \pm .21^{\mathrm{ab}}$ & $1.52 \pm .26^{\mathrm{a}}$ & $1.01 \pm .09^{\mathrm{b}}$ \\
\hline ANPU (\%) & $10.81 \pm .05^{\mathrm{c}}$ & $11.69 \pm .05^{\mathrm{b}}$ & $13.52 \pm .02^{\mathrm{a}}$ & $13.57 \pm .08^{\mathrm{a}}$ \\
\hline Survival (\%) & $84.33 \pm 16.78^{\mathrm{a}}$ & $77.45 \pm 36.52^{\mathrm{a}}$ & $83.57 \pm 16.54^{\mathrm{a}}$ & $97 \pm 1.00^{\mathrm{a}}$ \\
\hline
\end{tabular}

Figure in the same row with the same letters are significantly different $(P<0.05)$

The ANPU values in the present study indicate better assimilation of protein by fish (Table 3). Significantly higher ANPU value was found in case of fish fed on the diet 4 . Some previous studies showed that feeding rate decreased with increasing dietary meat and bone meal because of reduced palatability (Williams and Barlow, 1996) which accounted for growth reduction (Rodriguez et al., 1996, Robaina et al., 1997, Xue and Cui, 2001). In the present study satiation feeding was employed and the feeding rate was not different among dietary treatments. Growth performance was found best in the diet 4 where the feed had meat and bone meal as protein base instead of fish meal base. The result seems to be contradictory when compared with the finding of Rodriguez et al. (1996), Robaina et al. (1997) and Xue and Cui (2001). This result may be due to the basic differences in MBM quality or other unknown factors.

The proximate carcass composition (\% fresh matter basis) of fish at the start and end of experiment was presented in Table 4. The protein and ash content of the final carcass composition were markedly increased compared to that of initial carcass composition. The highest moisture content was found in diet 1 and the lowest was found in diet 4 . The significantly highest $(P<0.05)$ protein $(11.99 \%)$ was found in fish fed with diet 4 and significantly lowest (11.08) protein was found in fish fed with diet 1 . The significantly highest $(P<0.05)$ ash $(4.44 \%)$ was found in diet 3 and significantly lowest $(4.25 \%)$ ash was found in diet 1. With increasing content of MBM in the feed the carcass content of fry increases. The highest lipid content was found in diet 4 and the lowest was found in diet-1.

Table 4. Carcass composition of the fish sample at the start and end of the experiment (\% fresh matter basis)

\begin{tabular}{|c|c|c|c|c|c|}
\hline \multirow{2}{*}{ Components } & \multirow{2}{*}{ Initial (All fish) } & \multicolumn{4}{|c|}{ Final (Mean \pm SD) } \\
\cline { 3 - 6 } & & diet 1 & diet 2 & $\operatorname{diet~3~}$ & diet 4 \\
\hline Moisture & 87.29 & $82.37 \pm 1.02^{\mathrm{a}}$ & $81.87 \pm .90^{\mathrm{a}}$ & $82.21 \pm .54^{\mathrm{a}}$ & $81.57 \pm .90^{\mathrm{a}}$ \\
\hline Protein & 7.31 & $11.08 \pm .36^{\mathrm{b}}$ & $11.13 \pm .62^{\mathrm{b}}$ & $11.39 \pm .14^{\mathrm{ab}}$ & $11.99 \pm .38^{\mathrm{a}}$ \\
\hline Lipid & 2.97 & $1.38 \pm .13^{\mathrm{a}}$ & $1.49 \pm .16^{\mathrm{a}}$ & $1.45 \pm .15^{\mathrm{a}}$ & $1.53 \pm .12^{\mathrm{a}}$ \\
\hline Ash & 1.07 & $4.25 \pm .05^{\mathrm{b}}$ & $4.28 \pm .04^{\mathrm{b}}$ & $4.44 \pm .13^{\mathrm{a}}$ & $4.28 \pm .04^{\mathrm{b}}$ \\
\hline Crude fibre and carbohydrate & Not done & Not done & Not done & Not done & Not done \\
\hline
\end{tabular}

Figure in the same row with the different letters are significantly different $(P<0.05)$ 
Previous studies showed that there were no significant differences in body composition (protein, lipid, ash and moisture) among fish fed diets with graded levels of meat and bone meal (Robaina et al., 1997 and Bureau et al., 2000). Significantly $(P<0.05)$ high protein content was found in fish fed with diet 4 compared with control and others. There was no significant $(P>0.05)$ variation in the carcass lipid and moisture content of diets. However apparent higher carcass lipid content was observed in diet 2. The lipid and moisture content of fish showed an inverse relationship which was expected.

The cost of experimental diets was based on price of ingredients (Fish meal $56 \mathrm{Tk} / \mathrm{kg}$, Meat and bone meal $30 \mathrm{Tk} / \mathrm{kg}$, Rice bran $20 \mathrm{Tk} / \mathrm{kg}$ and Wheat flour $27 \mathrm{Tk} / \mathrm{kg}$ ) in the Mymensingh market in 2011. In terms of cost of the feed the control diet (diet 1) was found to be the most expensive (40.9 Tk/kg) and diet 4 was the cheapest $(27.0 \mathrm{Tk} / \mathrm{kg})$ one among the diets. Meat and bone meal based diets were found to be cheaper than the control (Table 5) and also from other diets (Table 5).

\section{Table 5. Cost per kg experimental diets (Taka)}

\begin{tabular}{|l|c|c|c|c|}
\hline Ingredients & Diet-1 & Diet-2 & Diet-3 & Diet-4 \\
\hline Fish meal & 28 & 14 & 7 & - \\
\hline Meat and bone meal & - & 8.13 & 12.19 & 16.23 \\
\hline Rice bran & 5.49 & 5.42 & 4.82 & 4.59 \\
\hline Wheat flour & 7.40 & 6.80 & 6.50 & 6.20 \\
\hline Total cost /kg diet & 40.89 & 34.35 & 30.51 & 27.02 \\
\hline
\end{tabular}

The result of the present study showed that the fry of $O$. niloticus can be successfully reared with diet 4 containing $54.06 \%$ Meat and bone meal, $22.97 \%$ Rice bran and $22.97 \%$ Wheat flour. Considering the growth performance, survival (\%) and profit the best result was obtained with diet 4 . The diet 4 was cheaper than control diet (45.15\% Fish meal, 27.43\% Rice bran and $27.43 \%$ Wheat flour). MBM could be used as a main protein source to replace fish meal without significant negative effect on growth and survival of $O$. niloticus fry. Thus the farmers can use a mixture of $54.06 \%$ Meat and bone meal, $22.97 \%$ Rice bran and $22.97 \%$ Wheat flour to reduce the cost of production. Further experiment with feed containing meat and bone meal instead of fish meal can be performed in different farms and also for a longer period of time to recommend the result in the farmers level.

\section{References}

AOAC (Association of Official Analytical Chemists), 2000. Official Methods of Analysis. $17^{\text {th }}$ edn. Association of Official Chemist, Washington DC. 2200 pp.

Bureau, D.P., Harris, A.M., Bevan, A.M., Simmons, D.J., Azevedo, L.A. and Cho, P.A. 2000. Feather meals and meat and bone meals from different origins as protein sources in rainbow trout (Oncorhynchus mykiss) diets. Aquacult., 181: 281-291.

Habib, M.A.B., Ullah, M.S., Hasan, M.R. and Akand, A.M. 2001. Use of silkworm pupae as partial replacement of fish meal in the diets with rotifer as feed additive of Asian catfish, Clarias batrachus fry. Bangladesh J. Fish., 24(1-2): 133-141.

Michael, C. and Jian, Z. 2002. Tilapia production in ponds with soy based feed. American soybean association. Result of ASA/China feeding trials. Beijing, China.5 pp.

Ogunji, J., Toor, R.S. and Clous, W. 2007. Growth performance, nutrient utilization of Nile tilapia (Oreochromis niloticus) fed housefly maggot meal diets. Turkish J. Fish.Aqua. Sci., 8: 141-147.

Robaina, L., Moyano, F.J., Izquierdo, M.S., Socorro, J., Vergara, J.M. and Montero, D. 1997. Corn gluten and meat and bone meal as protein sources in diets for gillhead sea bream (Sparus aurata): nutrition and histological implications. Aquaculture, 157: 347-359. 
Rodriguez, S.M., Olvera, N.M. and Carmona, O.C. 1996. Nutritional value of animal by-product meal in practical diets for Nile tilapia, Oreochromis niloticus. Aquacult. Res., 27: 67-73.

Sumi, K.R. 2011. Effect of different protein levels of fry feed on the production of quality tilapia (Oreochromis niloticus) fry. M.S. Thesis. Department of Aquaculture, BAU. $60 \mathrm{pp}$.

Williams, K.C. and Barlow, C.R. 1996. Nutritional research in Australia to improve pelleted diets for growout barramundi. In : knngkeo, H., cabanban, A.S.(Eds.), Aquacult. of Coas. Fish an Sus. Reef Fish., NACA and Pacific, Bangkok, Thailand.

Xue, M. and Cui, Y. 2001. Effect of several feeding stimulants on diet preference by juvenile gibel carp (Carassius auratus gibelio), fed diets with or without partial replacement of fish meal by meat and bone meal. Aquaculture, 198(3-4): 281-292. 